\title{
Effects of different physical forms of concentrate on performance, carcass characteristics, and economic analysis in hanwoo steers
}

\author{
Sung II Kim', Bo cheon Seo ${ }^{2}$, In Surk Jang ${ }^{2}$, Ouk Kim ${ }^{3}$, Chang Bon Choi ${ }^{4}$ and Keun Ki Jung ${ }^{5^{*}}$
}

\begin{abstract}
This study was performed to investigate the effects of different forms of concentrate fed to Hanwoo steers on performance, carcass characteristics, and economic performance. Forty-two Hanwoo steers (average age of $5.1 \pm 0.8 \mathrm{mo}$. with body weight of $147.05 \pm 10.85 \mathrm{~kg}$ ) were randomly allotted into FC (animals fed flakes for entire experimental period) and GC (animals fed grounded concentrate during growing and fattening phases followed by flaked concentrate during finishing phase) groups for $758 \mathrm{~d}$ after reaching an age of $30.0 \pm 0.82 \mathrm{mo}$. There was no difference in body weight (BW) or ADG between the treatments until fattening (15 $22 \mathrm{mo}$.) phase. However, by finishing phase (23 $30 \mathrm{mo}$.), the GC group (739.24 kg BW and $0.67 \mathrm{~kg} \mathrm{ADG}$ ) showed greater $(P<0.05) B W$ and ADG than the FC group (702.93 kg BW and $0.59 \mathrm{~kg} \mathrm{ADG})$. Steers in the GC group also showed greater $(P<0.05)$ BW and ADG than the FC group throughout the entire experimental period (5 $30 \mathrm{mo}$.). There was no significant difference in carcass weight or backfat thickness between the treatments. M. Longissimus dorsi area of the $\mathrm{GC}$ group $\left(91.00 \mathrm{~cm}^{2}\right)$ was greater $(P<0.05)$ than that of the FC group $\left(83.59 \mathrm{~cm}^{2}\right)$. Marbling score and percentage of $1^{++}$meat quality grade were 14.0 and $48.0 \%$ higher in the GC group compared to the FC group. There was no significant difference in physicochemical characteristics, including moisture and crude protein levels, between the treatments. Gross income per head excluding operating expenses was $59.3 \%$ greater in the GC group (1,647,512 won) compared to the FC group (1,034,343 won).
\end{abstract}

Keywords: Hanwoo steers, Flaked concentrate, Grounded concentrate, Economic performance

\section{Background}

The current trend in feeding systems for Hanwoo steers in Korea involves administration of animal feeds in the form of pellets or flakes rather than as grounded feeds. Pellets are formed by grounding and compressing raw ingredients into the shape of a pellet while flakes are processed using high heat and pressure. Hanwoo steers are fed grain-oriented compound feeds to increase their intake and efficiency [1]. However, production costs of Hanwoo farms are rapidly increasing due to skyrocketing prices of grains and animal feeds. As such, there is increasing demand to fortify the competitiveness of the Hanwoo industry by cutting down on production costs, and the most effective method may be simplifying the entire animal feed process. Processing of feedstuffs increases

\footnotetext{
*Correspondence: kkjung@ynu.ac.kr

${ }^{5}$ Moksan Hanwoo Reserch Institute, 108-7, Bujeok-ri, Apryang-myun, Gyeongsan, Gyeongsangbuk-do 712-821, Korea

Full list of author information is available at the end of the article
}

the gelatinization and digestibility of starch, ultimately improving feed efficiency [2]. Gelatinization of starch can be increased by pelleting and flaking by $35 \%$ and $50 \%$, repectively $[3,4]$. The range of this processing effect and feed efficiency depend on the type of grain, processing method, origin of feed ingredients, and breeding period of cattle $[5,6]$. Therefore, it is necessary to appropriately adjust the processing method of feed with regard to the breeding period of Hanwoo steers. To this end, this study investigated the effects of administration of various physical forms of grain feed during different feeding phases on performance, carcass characteristics, and economic performance in Hanwoo steers, thereby reducing production costs with efficient feed processing methods.

\section{Materials and methods}

\section{Experimental animals and design}

Forty-two Hanwoo steers (average age of $5.1 \pm 0.8 \mathrm{mo}$. with body weight of $147.05 \pm 10.85 \mathrm{~kg}$ ) were randomly 
allotted into FC (animals fed flakes for entire experimental period; growing, fattening, and finishing phases, $5 \sim 30$ mo. of age) and GC (animals fed grounded concentrate during growing, $5 \sim 14$ mo. of age, and fattening phases, $15 \sim 22$ mo. of age, followed by flakes during finishing phase, $23 \sim 30$ mo. of age). Hanwoo steers in the FC (18 steers divided into three pens) and GC (24 steers divided into four pens) groups were administered the assigned diets for $758 \mathrm{~d}$ after reaching an age of $30.0 \pm 0.82$ mo. (Table 1). The animals were sacrificed for meat production and parts of the carcass were used for the analysis with consent from the farmers in this study.

\section{Experimental diets}

Experimental diets were formulated by an animal feed manufacturing company located in Kimhae, Korea. Roughages used in this study included timothy, alfalfa, and tall fescue. Chemical compositions of the experimental diets are shown in Table 2 (concentrate) and 3 (roughage). Table 4 shows the physicochemical characteristics of corns. Amounts of concentrate and roughages used in the experimental diets were determined by considering the growth stage and nutrient requirements of the animals (Table 5).

\section{Feeding management}

Each treatment group was placed in a $5.0 \mathrm{~m} \times 10.0 \mathrm{~m}$ pen (six animals per pen) and administered the assigned diets twice per day. All animals had ad libitum access to water. Feed intake was recorded every day, and animals were weighed every month throughout the experiment. Animals were cared and managed according to Korean traditional farm regulations.

\section{Meat quality measurement}

At the end of the experimental period, animals were fasted for $24 \mathrm{~h}$, weighed, and slaughtered at a commercial abattoir located in Ansung, Kyunggi province, Korea. Carcass measurement were obtained after chilling for $24 \mathrm{~h}$ at $4^{\circ} \mathrm{C}$. Carcass yield and quality were graded by meat graders using the criteria provided by Livestock Quality Assessment [7].

Table 1 Feeding regimen of concentrate diet for the entire experiment

\begin{tabular}{llll}
\hline Treatment & Phases & \\
\cline { 2 - 4 } & Growing $^{\text {1) }}$ & Fattening $^{\text {2) }}$ & Finishing $^{\text {3) }}$ \\
\hline FC & $\begin{array}{l}\text { Flaked \& } \\
\text { pelleted diet }\end{array}$ & $\begin{array}{l}\text { Flaked \& } \\
\text { pelleted diet }\end{array}$ & Flaked \& pelleted diet \\
GC & Ground diet & Ground diet & Flaked \& pelleted diet
\end{tabular}

\footnotetext{
${ }^{1)}$ Feeding period: 5.1 to 13.9 months of age.

${ }^{2)}$ Feeding period: 13.9 to 22.1 months of age.

${ }^{3)}$ Feeding period: 22.1 to 30.0 months of age.
}

\section{Evaluation of carcass chemical composition a. Chemical composition}

Chemical composition, including moisture, ash, crude protein, and fat contents, were analyzed according to the AOAC methodology [8]. Moisture content (\%) of loin muscle samples $(2 \mathrm{~g})$ was measured by homogenizing and drying samples at $105^{\circ} \mathrm{C}$ in an oven and then measuring weight loss after drying. Total lipids were analyzed by the soxhelt extraction method. Crude protein content was measured by the Kjeldahl method. Briefly, $0.5 \mathrm{~g}$ of loin samples was digested at $450^{\circ} \mathrm{C}$ for $5 \mathrm{~h}$, distilled by addition of $50 \% \mathrm{NaOH}$, and titrated with $\mathrm{HCL}$, after which the total protein amount was calculated by multiplying\% $\mathrm{N}$ by 6.25 .

\section{b. Meat color}

Meat color, including Hunter L (lightness), a (redness), and b (yellowness), was determined by a Chroma Meter (CR-10, Minolta Corporation, LTD, Japan).

\section{c. Melting point}

Melting point was measured by the slip-point method. Briefly, lipids were extracted from meat samples by cutting them into small pieces with a Hanil Mini Cooking Cutter (Hanil electric co. HMC-150 T), homogenization with chloroform and methanol $(2: 1 \mathrm{v} / \mathrm{v})$ solution, filtration, and then evaporation with nitrogen. Capillary tubes (100 mm, open) were filled to a height of $1 \mathrm{~cm}$ from one end and then placed in a freezer $\left(-20^{\circ} \mathrm{C}\right)$ until lipids were firm (about $24 \mathrm{~h}$ ). After removal from the freezer, the capillary tube was place on a warm incubator, and the temperature was increased at a rate of $1^{\circ} \mathrm{C}$ per min. with stirring until the lipids melted.

\section{Economic analysis}

We analyzed the economic values of Hanwoo steers used in this experiment by calculating the average carcass prices at four different slaughter points. Profits from by-products were also considered as economic values. Feed costs for both the concentrate and roughage used in this analysis were applied as the actual purchase price of the farm where this experiment was performed. Costs for purchasing the calves, bedding, medicine, utilities (water and heating), and castration were averaged based on the number of animals used in this experiment.

\section{Statistics}

Data was analyzed by t-test of SAS [9]. Probability values less than $0.05 \%$ were considered significant. Data of feed intake and feed conversion rate from the breeding group were excluded from the significance test. 
Table 2 Chemical composition of concentrate diets

\begin{tabular}{|c|c|c|c|c|c|c|}
\hline \multirow[t]{3}{*}{ Composition } & \multicolumn{6}{|l|}{ Concentrate } \\
\hline & \multicolumn{2}{|l|}{ Growing } & \multicolumn{2}{|l|}{ Fattening } & \multicolumn{2}{|l|}{ Finishing } \\
\hline & Flaked & Ground & Flaked & Ground & Flaked & Flaked \\
\hline & \multicolumn{6}{|c|}{$\longrightarrow$, as - fed $\longrightarrow$} \\
\hline Moisture & $11.78 \pm 0.12^{1)}$ & $11.82 \pm 0.05$ & $12.67 \pm 0.06$ & $12.90 \pm 0.04$ & $12.59 \pm 0.09$ & $12.59 \pm 0.09$ \\
\hline Crude protein & $16.22 \pm 0.01$ & $16.33 \pm 0.02$ & $15.33 \pm 0.04$ & $15.18 \pm 0.03$ & $13.26 \pm 0.03$ & $13.26 \pm 0.03$ \\
\hline Crude fat & $3.06 \pm 0.01$ & $2.63 \pm 0.04$ & $3.03 \pm 0.03$ & $3.19 \pm 0.04$ & $3.17 \pm 0.06$ & $3.17 \pm 0.06$ \\
\hline Crude fiber & $11.74 \pm 0.25$ & $13.13 \pm 0.08$ & $10.15 \pm 0.06$ & $10.17 \pm 0.10$ & $9.24 \pm 0.39$ & $9.24 \pm 0.39$ \\
\hline Crude ash & $5.44 \pm 0.06$ & $6.03 \pm 0.05$ & $4.89 \pm 0.02$ & $5.04 \pm 0.06$ & $4.57 \pm 0.20$ & $4.57 \pm 0.20$ \\
\hline NFE & $51.76 \pm 1.61$ & $50.06 \pm 1.32$ & $53.93 \pm 1.11$ & $53.52 \pm 1.46$ & $57.17 \pm 0.95$ & $57.17 \pm 0.95$ \\
\hline $\mathrm{Ca}$ & $0.77 \pm 0.04$ & $0.66 \pm 0.01$ & $0.59 \pm 0.01$ & $0.63 \pm 0.02$ & $0.54 \pm 0.06$ & $0.54 \pm 0.06$ \\
\hline P & $0.45 \pm 0.00$ & $0.44 \pm 0.00$ & $0.40 \pm 0.00$ & $0.43 \pm 0.00$ & $0.41 \pm 0.02$ & $0.41 \pm 0.02$ \\
\hline$N^{2} F^{2)}$ & $29.04 \pm 0.36$ & $33.54 \pm 0.21$ & $26.06 \pm 0.07$ & $25.33 \pm 0.07$ & $27.85 \pm 1.37$ & $27.85 \pm 1.37$ \\
\hline $\mathrm{ADF}^{3)}$ & $16.18 \pm 0.19$ & $15.63 \pm 0.24$ & $14.75 \pm 0.10$ & $14.34 \pm 0.07$ & $13.58 \pm 0.38$ & $13.58 \pm 0.38$ \\
\hline $\mathrm{TDN}^{4)}$ & 68.0 & 68.0 & 70.0 & 70.0 & 72.0 & 72.0 \\
\hline
\end{tabular}

${ }^{1)}$ Means \pm standard error.

${ }^{2)}$ Neutral derergent fiber.

${ }^{3)}$ Acid detergent fiber.

${ }^{4)}$ Calculated.

\section{Results and discussion}

\section{Performance}

Changes in body weight $(\mathrm{BW})$ and $\mathrm{ADG}$ in steers fed the experimental diets are shown in Table 6. There was no significant difference in BW or ADG between the treatments during growing $(5 \sim 14$ mo.) and fattening $(15 \sim 22$ mo.) phases. However, by finishing phase $(23 \sim 30$ mo.), the GC group (739.24 kg BW and $0.67 \mathrm{~kg}$ ADG) showed greater $(\mathrm{P}<0.05) \mathrm{BW}$ and $\mathrm{ADG}$ than the $\mathrm{FC}$ group (702.93 kg BW and 0.59 kg ADG). Consistent with this result, steers in the GC group also showed greater $(\mathrm{P}<0.05) \mathrm{BW}$ and ADG than the FC group throughout the entire experimental period ( $5 \sim 30$ mo.). There was no significant difference in feed intake for either concentrate or roughage between the treatments during growing and fattening phases (Table 7). Feed intake for concentrate was $7.4 \%$ higher in the GC group compared to the FC group, whereas the feed conversion rate was $6.7 \%$ lower in the GC group compared to the FC group during finishing phase. The GC group showed a 3.0\% greater feed

Table 3 Chemical composition of roughages

\begin{tabular}{|c|c|c|c|c|}
\hline \multirow[t]{2}{*}{ Composition } & \multicolumn{4}{|l|}{ Roughages } \\
\hline & Timothy hay & Alfalfa hay & Tall fescue straw & Ryegrass straw \\
\hline & \multicolumn{4}{|c|}{$\longrightarrow$, as-fed basis -} \\
\hline Moisture & $8.22 \pm 0.07^{1)}$ & $9.64 \pm 0.18$ & $9.76 \pm 0.44$ & $7.72 \pm 0.04$ \\
\hline Crude protein & $7.87 \pm 0.18$ & $17.79 \pm 0.16$ & $7.06 \pm 0.59$ & $5.39 \pm 0.16$ \\
\hline Crude fat & $1.89 \pm 0.02$ & $1.97 \pm 0.02$ & $0.77 \pm 0.00$ & $1.10 \pm 0.05$ \\
\hline Crude fiber & $32.77 \pm 0.28$ & $27.71 \pm 0.32$ & $32.57 \pm 1.63$ & $32.34 \pm 0.19$ \\
\hline Crude ash & $6.37 \pm 0.12$ & $9.20 \pm 0.10$ & $5.97 \pm 0.76$ & $5.82 \pm 0.07$ \\
\hline $\mathrm{NFE}^{2)}$ & $42.88 \pm 0.74$ & $33.69 \pm 0.97$ & $43.87 \pm 2.54$ & $47.63 \pm 0.19$ \\
\hline $\mathrm{Ca}$ & $0.28 \pm 0.00$ & $1.48 \pm 0.02$ & $0.20 \pm 0.01$ & $0.36 \pm 0.01$ \\
\hline P & $0.16 \pm 0.00$ & $0.22 \pm 0.00$ & $0.08 \pm 0.01$ & $0.13 \pm 0.00$ \\
\hline $\mathrm{NDF}^{3)}$ & $59.99 \pm 0.30$ & $37.70 \pm 0.43$ & $59.42 \pm 1.93$ & $60.88 \pm 0.10$ \\
\hline $\mathrm{ADF}^{4)}$ & $34.36 \pm 0.23$ & $30.71 \pm 0.68$ & $34.20 \pm 1.78$ & $34.45 \pm 0.15$ \\
\hline $\mathrm{TDN}^{5)}$ & 54.61 & 53.55 & 34.18 & 52.82 \\
\hline
\end{tabular}

${ }^{1)}$ Means \pm standard error.

${ }^{2)}$ Nitrogen-free extract.

${ }^{3)}$ Neutral derergent fiber.

${ }^{4)}$ Acid detergent fiber.

${ }^{5)}$ Calculated. 
Table 4 Physicochemical characteristics and distribution of particle size in flake and grounded corns

\begin{tabular}{lll}
\hline Items & Flaked corn & Ground corn \\
\hline Flake thickness ${ }^{1)}, \mathrm{mm}$ & $3.29 \pm 0.04^{2)}$ & - \\
Starch gelatinization & \\
De $\%$ & $31.93 \pm 1.69$ & - \\
Density, g/l & $506.8 \pm 2.0$ & $693.5 \pm 2.5$ \\
Particle size ${ }^{4)}, \%$ & & \\
Sieve mesh & & \\
$6 \sim 8$ & - & $36.1 \pm 2.8$ \\
$14 \sim 18$ & - & $45.3 \pm 4.3$ \\
$25 \sim 40$ & - & $10.9 \pm 1.3$ \\
$60 \sim 100$ & - & $6.2 \pm 0.6$ \\
Under 100 & - & $1.5 \pm 0.4$ \\
\hline
\end{tabular}

${ }^{1)}$ Measured by vernier calipers.

${ }^{2)}$ Means \pm standard error.

3) Determined by diastase method.

${ }^{4)}$ Percents retained on screen. intake for concentrate as well as a 3.3\% lower feed conversion rate compared to the FC group for the entire experimental period. There was no significant difference in feed intake for roughage between the treatment groups. These results indicate that the physical form of concentrate have no affect on the ADG or feed intake of steers during growing and fattening phases. Zinn and Barajas [10] also reported that steers administered various densities of corn and barley for $86 \mathrm{~d}$ showed no difference in body weight gain or ADG. Consistent with these results, administration of various densities of sorghum flakes (412, 360, 309, and $257 \mathrm{~g} / \mathrm{L}$ ) did not affect the ADG of steers during growing phase [11]. However, in our study, steers from the GC group during finishing phase showed higher $(\mathrm{P}<0.05) \mathrm{BW}$ and ADG than those from the FC group. This result might be associated increased feed intake in the GC group. Furthermore, in a previous report, steers fed mashed concentrate during growing phase and then

Table 5 Feeding program for Hanwoo steers in the experiment

\begin{tabular}{|c|c|c|c|c|c|c|c|c|c|c|}
\hline \multirow[t]{2}{*}{$\begin{array}{l}\text { Fattening } \\
\text { phase }\end{array}$} & \multirow[t]{2}{*}{$\begin{array}{l}\text { Age in } \\
\text { mon. }\end{array}$} & \multirow[t]{2}{*}{$\begin{array}{l}\text { Body weight } \\
\text { range }(\mathbf{k g})\end{array}$} & \multirow[t]{2}{*}{$\begin{array}{l}\text { Daily gain } \\
(\mathrm{kg})\end{array}$} & \multirow[t]{2}{*}{$\begin{array}{l}\text { Feeding level } \\
\text { (body weight,\%) }\end{array}$} & \multicolumn{3}{|c|}{$\begin{array}{c}\text { Concentrate fed } \\
\text { (kg/hd/d, as-fed basis) }\end{array}$} & \multicolumn{3}{|c|}{$\begin{array}{c}\text { Roughage fed } \\
\text { (kg/hd/d, as-fed basis) }\end{array}$} \\
\hline & & & & & Growing & Fattening & Finishing & Timothy hay & Alfalfa hay & Straw \\
\hline \multirow[t]{9}{*}{ Growing } & 5 & $147 \sim 162$ & 0.50 & 0.90 & 1.4 & & & 1.5 & 0.5 & \\
\hline & 6 & $162 \sim 188$ & 0.85 & 1.25 & 2.0 & & & 2.0 & 1.0 & \\
\hline & 7 & $188 \sim 214$ & 0.85 & 1.40 & 2.6 & & & 3.0 & 1.0 & \\
\hline & 8 & $214 \sim 241$ & 0.90 & 1.50 & 3.2 & & & 3.4 & 1.0 & \\
\hline & 9 & $241 \sim 268$ & 0.90 & 1.50 & 3.6 & & & 3.5 & 1.0 & \\
\hline & 10 & $268 \sim 295$ & 0.90 & 1.53 & 4.1 & & & 4.0 & 1.0 & \\
\hline & 11 & $295 \sim 322$ & 0.90 & 1.55 & 4.6 & & & 4.0 & 1.0 & \\
\hline & 12 & $322 \sim 351$ & 0.95 & 1.61 & 5.2 & & & 4.5 & 0.5 & \\
\hline & 13 & $351 \sim 379$ & 0.95 & 1.70 & 6.0 & & & 4.5 & 0.5 & \\
\hline \multirow[t]{9}{*}{ Fattening } & 14 & $379 \sim 408$ & 0.95 & 1.84 & 3.5 & 3.5 & & 4.5 & & \\
\hline & 15 & $408 \sim 436$ & 0.95 & 1.96 & & 8.0 & & 3.5 & & 0.5 \\
\hline & 16 & $436 \sim 466$ & 1.00 & 2.06 & & 9.0 & & & & 3.0 \\
\hline & 17 & $466 \sim 496$ & 1.00 & 2.08 & & 9.7 & & & & 3.0 \\
\hline & 18 & $496 \sim 526$ & 1.00 & 2.02 & & 10.0 & & & & 2.5 \\
\hline & 19 & $526 \sim 553$ & 0.90 & 1.90 & & 10.0 & & & & 2.3 \\
\hline & 20 & $553 \sim 579$ & 0.85 & 1.81 & & 10.0 & & & & 2.0 \\
\hline & 21 & $579 \sim 604$ & 0.85 & 1.73 & & 10.0 & & & & 1.5 \\
\hline & 22 & $604 \sim 628$ & 0.80 & 1.66 & & 10.0 & & & & 1.5 \\
\hline \multirow[t]{8}{*}{ Finishing } & 23 & $628 \sim 649$ & 0.70 & 1.51 & & & 9.5 & & & 1.3 \\
\hline & 24 & $649 \sim 667$ & 0.60 & 1.39 & & & 9.0 & & & 1.2 \\
\hline & 25 & $667 \sim 682$ & 0.50 & 1.35 & & & 9.0 & & & 1.2 \\
\hline & 26 & $682 \sim 696$ & 0.45 & 1.25 & & & 8.5 & & & 1.2 \\
\hline & 27 & $696 \sim 708$ & 0.40 & 1.22 & & & 8.5 & & & 1.2 \\
\hline & 28 & $708 \sim 718$ & 0.35 & 1.13 & & & 8.0 & & & 1.2 \\
\hline & 29 & $718 \sim 727$ & 0.30 & 1.11 & & & 8.0 & & & 1.2 \\
\hline & 30 & $727 \sim 736$ & 0.30 & 1.03 & & & 7.5 & & & 1.2 \\
\hline
\end{tabular}


Table 6 Body weight and daily gain of Hanwoo steers by treatment

\begin{tabular}{llll}
\hline Items & $\mathbf{F C}^{\mathbf{1}}$ & $\mathbf{G C}^{\mathbf{2}}$ & T-test $^{\mathbf{3}}$ \\
\hline No. of heads & 18 & 24 & \\
$\begin{array}{l}\text { Body weight (kg) } \\
\quad \text { Initial (5 mo) }\end{array}$ & $146.7 \pm 1.35$ & $147.4 \pm 0.99$ & 0.9253 \\
Growing (14 mo) & $370.7 \pm 1.81$ & $374.5 \pm 1.22$ & 0.6985 \\
$\quad$ Fattening (22 mo) & $562.2 \pm 2.47$ & $575.1 \pm 1.90$ & 0.2297 \\
$\quad$ Finishing (30 mo) & $702.9 \pm 2.90$ & $739.2 \pm 2.67$ & 0.0483 \\
Average daily gain (kg) & & & \\
$\quad$ Growing phase & $0.84 \pm 0.00$ & $0.85 \pm 0.00$ & 0.6629 \\
Fattening phase & $0.77 \pm 0.01$ & $0.80 \pm 0.01$ & 0.3220 \\
Finishing phase & $0.59 \pm 0.00$ & $0.67 \pm 0.01$ & 0.0548 \\
Overall period & $0.73 \pm 0.00$ & $0.78 \pm 0.00$ & 0.0414
\end{tabular}

1)Growing (flaked \& pelleted diet), fattening (flaked \& pelleted diet) \& finishing (flaked \& pelleted diet).

${ }^{2)}$ Growing (ground diet), fattening (ground diet) \& finishing (flaked \& pelleted diet).

3) Probability of the T test.

switched to flaked concentrate during finishing phase showed a greater (by $0.98 \mathrm{~kg}$ ) ADG compared to those fed flaked concentrate for the entire period [12]. Flaking improves the feed conversion rate by inducing gelatinization of starch [13]. On the other hand, administration of flaked concentrate for the entire feeding period may decrease feed intake by reducing the rumen $\mathrm{pH}$, which is associated with accelerated degradation of starch [14]. Taken together, feeding steers grounded concentrate during growing and fattening phases and then switching to flaked concentrate finishing phase effectively improved ADG and feed intake.

\section{Carcass characteristics}

Carcass weight, backfat thickness, M. Longissimus dorsi area, marbling score, and meat color of Hanwoo steers fed the experimental diets are shown in Table 8. Carcass weight of the GC group (4229.57 kg) was numerically, but not statistically, higher than that of the FC group $(405.94 \mathrm{~kg})$. There was no significant difference in backfat thickness between the treatments. M. Longissimus dorsi area of the GC group $\left(91.00 \mathrm{~cm}^{2}\right)$ was greater $(\mathrm{P}<0.05)$ than that of the FC group $\left(83.59 \mathrm{~cm}^{2}\right)$. Marbling score, which is a meat quality trait, was $18.4 \%$ higher in the GC group (6.96) compared to the FC group (5.88). No difference was found in meat color, fat color, texture, or maturity between the treatments. The GC group showed a higher percentage of $1^{++}$grade (43.5\%) compared to the FC group (29.4\%) by $48 \%$. Percentage of quality grade over $1^{+}$grade was also higher in the GC group (87\%) than in the FC group (29.4\%) by $50 \%$. Brandt et al [15] also reported that supplementation of steam-flaked corn to steers increases the M. Longissimus dorsi area. However, carcass weight and backfat thickness are not affected by densities of
Table 7 Feed intake and feed conversion in Hanwoo steers

\begin{tabular}{|c|c|c|}
\hline Items & $\mathrm{FC}^{1)}$ & $\mathrm{GC}^{2)}$ \\
\hline \multicolumn{3}{|l|}{ Growing phase } \\
\hline \multicolumn{3}{|l|}{ Feed intake (kg/head/day) } \\
\hline Concentrate & 3.52 & 3.53 \\
\hline Timothy hay & 2.60 & 2.78 \\
\hline Alfalfa hay & 0.68 & 0.70 \\
\hline Sub-total & 3.28 & 3.48 \\
\hline Feed conversion, kg/kg & 8.14 & 8.27 \\
\hline \multicolumn{3}{|l|}{ Fattening phase } \\
\hline \multicolumn{3}{|l|}{ Feed intake (kg/head/day) } \\
\hline Concentrate & 7.91 & 7.89 \\
\hline Timothy hay & 1.01 & 0.91 \\
\hline Tall fescue straw & 0.80 & 0.99 \\
\hline Ryegrass straw & 0.10 & - \\
\hline Sub-total & 1.91 & 1.89 \\
\hline Feed conversion, kg/kg & 12.83 & 12.19 \\
\hline \multicolumn{3}{|l|}{ Finishing phase } \\
\hline \multicolumn{3}{|l|}{ Feed intake (kg/head/day) } \\
\hline Concentrate & 7.80 & 8.38 \\
\hline Tall fescue straw & - & 1.23 \\
\hline Ryegrass straw & 1.23 & - \\
\hline Sub-total & 1.23 & 1.23 \\
\hline Feed conversion, kg/kg & 15.39 & 14.38 \\
\hline
\end{tabular}

Overall period

Feed intake (kg/head/day)

$\begin{array}{lll}\text { Concentrate } & 6.32 & 6.50\end{array}$

Timothy hay $\quad 1.25 \quad 1.28$

Alfalfa hay $\quad 0.24 \quad 0.25$

$\begin{array}{lll}\text { Tall fescue straw } & 0.26 & 0.72\end{array}$

Ryegrass straw $\quad 0.42 \quad-$

$\begin{array}{lll}\text { Sub-total } & 2.18 & 2.25\end{array}$

Feed conversion, $\mathrm{kg} / \mathrm{kg} \quad 11.59 \quad 11.22$

${ }^{1)}$ Growing (flaked \& pelleted diet), fattening (flaked \& pelleted diet) \& finishing (flaked \& pelleted diet)

${ }^{2)}$ Growing (ground diet), fattening (ground diet) \& finishing (flaked \& pelleted diet).

flaked corn [16]. Moreover, consistent with our current results, NIAS [12] reported that administration of powdered concentrate during fattening phase followed by flaked concentrate during finishing phase to steers increased the marbling score by $13.3 \%$ compared to the flake-fed group for the entire period. In the current study, steers in the GC group showed improved M. Longissimus dorsi area and marbling score.

\section{Physicochemical characteristics of carcass}

Effects of various physical forms of feeds on the physicochemical characteristics of Hanwoo steers are shown in 
Table 8 Effects of physical forms of concentrate on carcass characteristics in Hanwoo steers

\begin{tabular}{|c|c|c|c|}
\hline Items & $\mathrm{FC}^{1)}$ & $\mathrm{GC}^{2)}$ & T- test $^{3)}$ \\
\hline \multicolumn{4}{|l|}{ Yield traits } \\
\hline Cold carcass, kg & $405.94 \pm 2.08^{4)}$ & $429.57 \pm 1.67$ & 0.0542 \\
\hline Backfat thickness, mm & $16.88 \pm 0.26$ & $17.96 \pm 0.22$ & 0.4892 \\
\hline Longissmus muscle area, $\mathrm{cm}^{2}$ & $83.59 \pm 0.48$ & $91.00 \pm 0.44$ & 0.0178 \\
\hline Yield index & $62.30 \pm 0.17$ & $61.71 \pm 0.14$ & 0.5568 \\
\hline \multicolumn{4}{|l|}{ Yield grade, $\%$} \\
\hline A & $0.0^{5)}$ & 0.0 & \\
\hline B & 58.8 & 47.8 & \\
\hline C & 41.2 & 52.2 & \\
\hline \multicolumn{4}{|l|}{ Quality traits } \\
\hline Marbling score ${ }^{6)}$ & $5.88 \pm 0.12$ & $6.96 \pm 0.06$ & 0.0650 \\
\hline Meat color ${ }^{7)}$ & $4.88 \pm 0.02$ & $4.65 \pm 0.02$ & 0.1014 \\
\hline Fat color ${ }^{8)}$ & $2.94 \pm 0.01$ & $2.78 \pm 0.02$ & 0.1735 \\
\hline Texture $^{9)}$ & $1.24 \pm 0.03$ & $1.04 \pm 0.01$ & 0.0729 \\
\hline Maturity $^{10)}$ & $2.35 \pm 0.03$ & $2.57 \pm 0.02$ & 0.1931 \\
\hline \multicolumn{4}{|l|}{ Quality grade, $\%$} \\
\hline $1^{++}$ & 29.4 & 43.5 & \\
\hline $1^{+}$ & 29.4 & 43.5 & \\
\hline 1 & 17.7 & 8.7 & \\
\hline 2 & 23.5 & 4.3 & \\
\hline
\end{tabular}

Table 9. Moisture levels of the M. Longissimus dorsi muscle from steers in the FC and GC groups were 62.91 and $61.48 \%$, respectively. Contents of crude protein in M. Longissimus dorsi muscle from steers in the FC and GC groups were 19.35 and $18.75 \%$, respectively. Crude fat content of the GC group (18.37\%) was greater than that of the FC group $(15.90 \%)$ by $15.5 \%$. The overall range of measured CIE values, including L (lightness), b (yellowness), and $\mathrm{h}$ (color), were greater $(\mathrm{P}<0.05)$ in the GC group compared to the FC group. Physicochemical properties of meat are normally affected by moisture and crude fat content [17]. Levels of crude fat and CIE values $(\mathrm{L})$ increase while moisture and crude proten content decrease with an increase in meat quality $[18,19]$. Physicochemical characteristics of beef might be preferentially related to meat quality grade rather than the physical form or processing method of feed [20]. Melting point of carcass fat was highest in perirenal fat, followed by intramuscular fat and then subcutaneous fat (Table 10). Although not significant, the melting points of subcutaneous fat and intramuscular fat were lower in the GC group
Table 9 Effects of physical forms of concentrate on physicochemical characteristics of M.longissimus dorsi muscle in Hanwoo steers

\begin{tabular}{llll}
\hline Items & $\mathbf{F C}^{1)}$ & $\mathbf{G C}^{\mathbf{2})}$ & T- test \\
\hline Moisture,\% & $62.91 \pm 0.19^{4)}$ & $61.48 \pm 0.17$ & 0.2246 \\
Crude fat,\% & $15.90 \pm 0.28$ & $18.37 \pm 0.22$ & 0.1240 \\
Crude protein,\% & $19.35 \pm 0.06$ & $18.75 \pm 0.05$ & 0.1058 \\
CIE value.5) & & & \\
L & $40.43 \pm 0.10$ & $43.35 \pm 0.07$ & 0.0016 \\
a & $23.35 \pm 0.06$ & $23.81 \pm 0.04$ & 0.3895 \\
b & $11.10 \pm 0.03$ & $11.77 \pm 0.02$ & 0.0242 \\
chroma & $25.76 \pm 0.06$ & $26.60 \pm 0.05$ & 0.1604 \\
hue & $25.36 \pm 0.04$ & $26.60 \pm 0.02$ & 0.0120 \\
Cooking loss,\% & $29.79 \pm 0.05$ & $28.62 \pm 0.07$ & 0.2096 \\
\hline
\end{tabular}

${ }^{1)}$ Growing (flaked \& pelleted diet), fattening (flaked \& pelleted diet) \& finishing (flaked \& pelleted diet).

${ }^{2)}$ Growing (ground diet), fattening (ground diet) \& finishing (flaked \& pelleted diet).

${ }^{3)}$ Probability of the $T$ test.

${ }^{4)}$ Means \pm standard error.

${ }^{5)} \mathrm{L}=$ lightness, $\mathrm{a}=$ redness, $\mathrm{b}=$ yellowness.

compared to the FC group by 4.0 and $3.0 \%$, respectively. Carcass fat melting point was the greatest in perireral fat, followed by intramuscular fat and then subcutaneous fat. Melting point is highly correlated with fatty acid composition rather than the type or processing method of feed [21]; a higher fatty acid content is associated with a lower melting point and vice versa [22]. Taken together, the GC group with a high marbling score and meat quality grade showed higher carcass physiocochemical properties, including crude fat content and CIE.

\section{Economic analysis}

Effects of various physical forms of concentrate on profitability are shown in Table 11. Carcass sale price for the FC and GC groups were 6,036,373 and 6,667,053 won (KRW), repectively. Carcass and by-product sale prices of the GC group were greater than those of the FC group by $10.0 \%$. Total operating expenses, including calf purchase expenses, feed, slaughter, and other expenses, increased by $0.5 \%$ in the GC group (5,360,702 won) compared to the FC group (5,334,848 won). Gross income per head excluding operating expenses was $59.3 \%$ greater in the GC group

Table 10 Effects of physical forms of concentrate on melting point of carcass fat in Hanwoo steers

\begin{tabular}{llll}
\hline Items & FC $^{\mathbf{1}}$ & $\mathbf{G C}^{\mathbf{2}}$ & T- $^{\text {test }}{ }^{\mathbf{3}}$ \\
\hline Perirenal fat & $38.82 \pm 0.05^{4)}$ & $39.49 \pm 0.03$ & 0.5825 \\
Subcutaneous fat & $21.39 \pm 0.03$ & $20.54 \pm 0.02$ & 0.3142 \\
Intramuscular fat & $26.81 \pm 0.05$ & $26.02 \pm 0.02$ & 0.6595 \\
\hline
\end{tabular}

${ }^{1)}$ Growing (flaked \& pelleted diet), fattening (flaked \& pelleted diet) \& finishing (flaked \& pelleted diet).

${ }^{2)}$ Growing (ground diet), fattening (ground diet) \& finishing (flaked \& pelleted diet).

${ }^{3)}$ Probability of the $T$ test.

${ }^{4)}$ Means \pm standard error. 
Table 11 Effects of physical forms of concentrate on profits in Hanwoo steers

\begin{tabular}{|c|c|c|}
\hline Items & $\mathrm{FC}^{1)}$ & $\mathrm{GC}^{2)}$ \\
\hline Cold carcass, kg & $405.94 \pm 2.08^{3)}$ & $429.57 \pm 1.67$ \\
\hline \multicolumn{3}{|l|}{ 1. Gross income(A) } \\
\hline Carcass sales ${ }^{4)}$ & $6,036,373.19$ & $6,667,053.48$ \\
\hline By-product sales ${ }^{5)}$ & 332,818 & 341,162 \\
\hline Total income & $6,369,191.19$ & $7,008,215.48$ \\
\hline \multicolumn{3}{|l|}{ 2. Operating $\operatorname{cost}(\mathrm{B})$} \\
\hline Calves & $2,430,952$ & $2,430,952$ \\
\hline Concentrate $^{6)}$ & $1,226,259.2$ & $1,226,740.2$ \\
\hline Roughage $^{7)}$ & $576,954.3$ & $593,850.3$ \\
\hline Butchery expense ${ }^{8)}$ & 227,044 & 235,522 \\
\hline Self-help funds & 20,000 & 20,000 \\
\hline Miscellaneous expenses ${ }^{9)}$ & 853,638 & 853,638 \\
\hline Total cost & $5,334,847.5$ & $5,360,702.5$ \\
\hline 3. Profit(A-B) & $1,034,343.69$ & $1,647,512.98$ \\
\hline
\end{tabular}

${ }^{1)}$ Growing (flaked \& pelleted diet), fattening (flaked \& pelleted diet) \& finishing (flaked \& pelleted diet).

${ }^{2)}$ Growing (ground diet), fattening (ground diet) \& finishing (flaked \& pelleted diet).

${ }^{3)}$ Means \pm standard error.

${ }^{4)}$ Carcass price, won $/ \mathrm{kg}: 1^{++} \mathrm{B}=17,413,1^{+} \mathrm{B}=15,133,1 \mathrm{~B}=14,290,1^{++} \mathrm{C}=16,507$,

$1^{+} \mathrm{C} 14,398,1=13,570,213,330,212,370$

${ }^{5)}$ Includes intestines, head, legs, hide, blood, and inedible fat.

${ }^{6)}$ Concentrate price, won/kg : Growing $(F)=266.8$,

Growing $(M)=256.0$, Fattening $(F)=264.0$,

Fattening $(M)=253.2$, Finishing $(F)=241.6$

${ }^{7)}$ Roughage price, won $/ \mathrm{kg}$ : Timothy hay $=407$, Alfalfa hay $=360$, Tall fescue

straw $=240$, Ryegrass straw $=240$

${ }^{8)}$ Butchery expense: tax, dissection operation, stamp duty, inspection \&

grading fee.

${ }^{9)}$ Miscellaneous expenses: hired labor, bedding materials, electricity, transport, water service \& veterinary \& medicine.

(1,647,512 won) compared to the FC group (1,034,343 won). This increase in total revenue in the GC group can be attributed to an elevated carcass weight and percentage of meat grade above $1^{+}$. Total operating expenses in the GC group were $7.5 \%$ greater than those in the FC group due to increased feed intake following replacement of grounded feed by flaked concentrate during finishing phase. Operating expenses in the GC group were also higher due to elevated slaughter expenses due to increased carcass weight. In conclusion, administration of grounded concentrate during growing and fattening phases followed by flaked concentrate during finishing phase improves the profit and productivity of Hanwoo steers.

\section{Conclusion}

This study was performed to investigate the effects of different forms of concentrate fed to Hanwoo steers on performance, carcass characteristics, and economic performance. In conclusion, it is plausible that feeding steers grounded concentrate during growing and fattening phases followed by flaked concentrate during finishing phase can improve ADG and feed intake. This feeding strategy increases the profit and productivity Hanwoo steers.

\section{Competing interests}

The authors declare that they have no competing interests.

\section{Authors' contributions}

SIK and BCS participated in the design of study and made farm visits. ISC and OK carried out the laboratory work. CBC performed the statistical analysis. KKJ made farm visits. All authors helped to draft the article and approved the final manuscript.

\section{Acknowledgements}

The authors sincerely thank Songchon farmers for their support during this study and for time spent during sampling and examination.

\section{Author details}

${ }^{1}$ Department of Animal Science, Gyeonbuk Provincial College, Yecheong-eup 757-807, Korea. ${ }^{2}$ Gyeongnam National University of Science and Technolony, Jinju 757-803, Korea. ${ }^{3}$ Department of Animal Science, Dong-A University, Busan 602-714, Korea. ${ }^{4}$ Department of Biotechnolony, Yeungnam University, Gyeongsan 712-749, Korea. ${ }^{5}$ Moksan Hanwoo Reserch Institute, 108-7, Bujeok-ri, Apryang-myun, Gyeongsan, Gyeongsangbuk-do 712-821, Korea.

Received: 25 April 2014 Accepted: 8 May 2014

Published: 28 July 2014

\section{References}

1. Jeong J, Jin GL, Shinekhuu J, Ji BJ, Song MK: Effect of method on nutrient availability in ruminants. Bull Biotechnol 2009, 2:13-21.

2. Hale WH, Cuitun L, Saba WJ, Taylor B, Theurer B: Effect of steam processing and flaking milo and barley on performance and digestion by steers. J Anim Sci 1966, 25:392-396.

3. Han YK, Maeng WJ, Park GK, Paik IK, Ohh SJ, Choi YJ: Feed Processings. Seoul, Korea: Sun Jin Mun Hwa Sa; 1993:473-475.

4. Theurer CB, Lozano O, Alio A, Delgado-Elorduy A, Sadik M, Huber JT, Zinn RA Steam-processed corn and sorghum grain flaked at different densities alter ruminal, small intestinal, and total tract digestibility of starch by steers. J Anim Sci 1999, 77:2824-2831.

5. Neock JE, Tamminga S: Site of digestion of starch in the gastrointestinal tract of dairy cows and its effect on milk yield and composition. J Dairy Sci 1991, 74:3598-3629.

6. Owens FN, Secrist DS, Hill EJ, Gill DR: The effect of grain source and grain processing on performance of feedlot cattle: a review. J Anim Sci 1997, 75:868-879.

7. Livestock Quality Assessment: Grading of Carcasses of Methods, Standards and Enforcement; 2007.

8. AOAC: Official Methods of Analysis. 15th edition. Arlington, Virginia USA: Association of Official Analytical Chemist; 1990.

9. SAS: SAS User's Guide:Statistics. NC: SAS Institute Inc. Cary; 2002.

10. Zinn RA, Barajas R: Influence of flake density on the comparative feeding value of a barley-corn blend for feedlot cattle. J Anim Sci 1997, 75:904-909.

11. Swingle RS, Eck TP, Theurer CB, De la Llata N, Poore MG, Moore JA: Flake density of steam-processed sorghum grain alters performance and sites of digestibility by growing-finishing steers. J Anim Sci 1999, 77:1055-1065.

12. National Institue of Aniamal Science: Development of technologies for production of high-quality beef from Hanwoo steers. In Effects of Physical Form of Concentrate on Productivity of Hawoo by Feeding Period. 1998:545.

13. Theurer $C B$ : Grain processing effect on starch utilization by ruminants. J Anim Sci 1986, 63:1649-1662.

14. Ministry of Ariculture, Food and Rural Affairs: Development of technologies to improve competitiveness of Hanwoo. In Development of feeding program for production of high-quality beef from Hanwoo steers. 2005:85-92.

15. Brandt RT Jr, Kuhl GL, Campbell RE, Kastner CL, Stroda SL: Effects of steam-flaked sorghum grain or corn and supplemental fat on feedlot performance, carcass traits, longissimus composition, and sensory properties of steers. J Anim Sci 1992, 70:343-348.

16. Hales KE, McMeniman JP, Leibovich J, Vasconcelos JT, Quinn MJ, May ML, DiLorenzo N, Smith DR, Galyean ML: Effects of varying bulk densities of steam-flaked corn and dietary roughage concentration on in vitro 
fermentation, performance, carcass quality, and acid-base balance measurements in finishing steers. J Anim Sci 2010, 88(3):1135-1147.

17. Kelly RF, Fontenot JP, Graham PP, Wilkinson WS, Kineaid CM: Estimates of carcass composition of beef cattle fed at different plane of nutrition. J Anim Sci 1968, 27:620-627.

18. Savell JW, Cross HR, Smith GC: Percentage ether extractable fat and moisture content of beef longissimus muscle as related to USDA marbling score. J Food Sci 1986, 51:838-840.

19. Nelson JL, Dolezal HG, Ray FK, Morgan JB: Characterization of certified angus beef steaks from the round, loin, and chuck. J Anim Sci 2004, 82:1437-1444.

20. Cameron PJ, Zembayashi M, Lunt DK, Mitsuhashi T, Mitsumoto M, Dzawa S, Smith SB: Relationship between Japanese Beef Marbling Standard and intramuscular lipid in the $\mathrm{m}$. longissimus thoracis of Japanese Black and American Wagyu cattle. Meat Sci 1994, 38:361-364.

21. Wood JD: Fat deposition and the quality of fat tissue in meat animals. In Fats in Animal Nutrition. Edited by Wiseman J. 1984:407-435.

22. Enser M, Wood JD: Effect of Time of Year on Fatty Acid Composition and Melting Point of UK Lamb, Proceeding of the 39th International congress of meat Science and Technology. 2nd edition. 1993:74.

doi:10.1186/2055-0391-56-9

Cite this article as: Kim et al:: Effects of different physical forms of concentrate on performance, carcass characteristics, and economic analysis in hanwoo steers. Journal of Animal Science and Technology 2014 56:9.

\section{Submit your next manuscript to BioMed Central and take full advantage of:}

- Convenient online submission

- Thorough peer review

- No space constraints or color figure charges

- Immediate publication on acceptance

- Inclusion in PubMed, CAS, Scopus and Google Scholar

- Research which is freely available for redistribution 